\title{
Poly(methylene-co-cyanoguanidine) as an Eco-friendly Nitrogen Fertilizer with Prolonged Activity
}

\author{
Piotr Rychter ${ }^{1}\left[\right.$ D $\cdot$ Diana Rogacz $^{1} \cdot$ Kamila Lewicka ${ }^{1} \cdot$ Igor Lacik $^{2}$
}

Published online: 28 March 2019

(c) The Author(s) 2019

\begin{abstract}
Poly(methylene-co-cyanoguanidine), PMCG, is an oligomeric polycation that has found its application in the waste-water treatment as well as in preparation of polyelectrolyte complex microcapsules for biomedical purposes. Considering the nitrogen-rich composition of repeating unit, PMCG may be a valuable polycation utilized as a novel slow-release fertilizer. The aim of this study was to evaluate the potential of PMCG as a nitrogen fertilizer during its 6-month incubation in the soil. Monocotyledonous oat (Avena sativa) and dicotyledonous radish (Raphanus sativus $\mathrm{L}$.) were selected as representative model plants for plant growth test. The effect of PMCG on plant growth and development was dependent on both the PMCG concentration and time of incubation. An increase in the nitrogen amount in green parts of plants demonstrated the uptake of the plant-available form of nitrogen released from PMCG incubated in the soil. This resulted in an increased percentage of fresh matter and shoot height of the tested plants during their exposure to PMCG. Ecotoxicological impact of PMCG in the soil during incubation period against bacteria Allivibrio fischeri and crustacean Heterocypris incongruens was also assessed. PMCG was found as the potential polymer fertilizer that does not require special treatment and can be used as it is for the prolonged release of nitrogen in agriculture.
\end{abstract}

Keywords Poly(methylene-co-cyanoguanidine) $\cdot$ PMCG $\cdot$ Controlled release system $\cdot$ Fertilizer with prolonged activity $\cdot$ Ecotoxicity

\section{Introduction}

Enhancement of the nitrogen-use efficiency in crops is a crucial goal in sustainable production system. Among all the plant nutrients essential for an efficient crop production, nitrogen plays the most important role in almost all metabolic activities in plants and is thus the most critical nutritional factor responsible for the achievement of optimum yields of all crops [1]. According to the Food and Agriculture Organization, the annual requirement of the nitrogenous fertilizer for crop plants is huge and reaches around 120 million metric tons [2].

Piotr Rychter

p.rychter@ajd.czest.pl

1 Faculty of Mathematics and Natural Science, Jan Długosz University in Częstochowa, 13/15 Armii Krajowej Av, 42-200 Czestochowa, Poland

2 Polymer Institute, Slovak Academy of Sciences, Dubravska cesta 9, 84541 Bratislava, Slovakia
Unfortunately, the application of excessive amount of nitrogen fertilizers leads to a number of serious environmental problems [3]. The excess application of nitrogen often results in the eutrophication of surface water, acidification of soils and water resources, and loss of biodiversity in terrestrial and aquatic ecosystems. The efficiency of applied nitrogenous fertilizers is dependent on their losses in the form of volatilization, leaching, surface runoff, and denitrification and increase of $\mathrm{N}_{2} \mathrm{O}$ emissions from soil-plant system. One of the strategies to solve the problem of an excessive loss of fertilizers to the environment is in using fertilizers exhibiting slow and controlled nutrients release from mostly biodegradable polymeric matrix like chitosan, starch derivatives, sodium alginate, polyhydroxybutyrate, ethyl cellulose, and lignin-based matrices [4-8]. Ni et al. investigated environmentally friendly slow-release formulations of a nitrogen fertilizer prepared on the basis of natural attapulgite clay, ethylcellulose film, and sodium carboxymethylcellulose/hydroxyethylcellulose hydrogel [9].

Agricultural residues, like wheat straw and corn stover (comprised of lignin, cellulose, and hemicelluloses), are 
considered as environmentally friendly nitrogen nutrients because they are the by-products of crop production. Such products provide organic matter and improve soil fertility during their degradation in soil [10]. In this context, a usefulness of starch films plasticized with urea as a fertilizer for improvement of plant growth has been shown by Rychter et al. [11]. Wastes of starch-based materials, regardless of their origin either from production process or from afteruse products, and plasticized with urea and glycerol, may be used as a fertilizer for supplying nitrogen for the plants in floriculture, horticulture, or agriculture. Nitrogen nutrition is a fundamental environmental factor for plant growth affecting considerably the production capacity of plant pigments in leaves. Chlorophyll plays an important role during photosynthesis and supports plant growth, and, together with carotenoids, it is a sensitive indicator of the damaging impact of various biotic and abiotic stresses on leaf function and health $[12,13]$.

Since the controlled release fertilizers immobilized in biodegradable polymers have been gaining a great interest in modern agricultural production to meet the criteria of environmental sustainability, ongoing investigations toward identifying fertilizers exhibiting prolonged activity are required. Among the polymers that contain nitrogen in their structure, poly(methylene-co-cyanoguanidine), PMCG (Fig. 1), attracted our attention as a potential fertilizer that may afford a prolonged release of nitrogen and possibly act as a plant nutrient.

Current applications of PMCG include, for example, the color removal in the industrial waste-water treatment in the

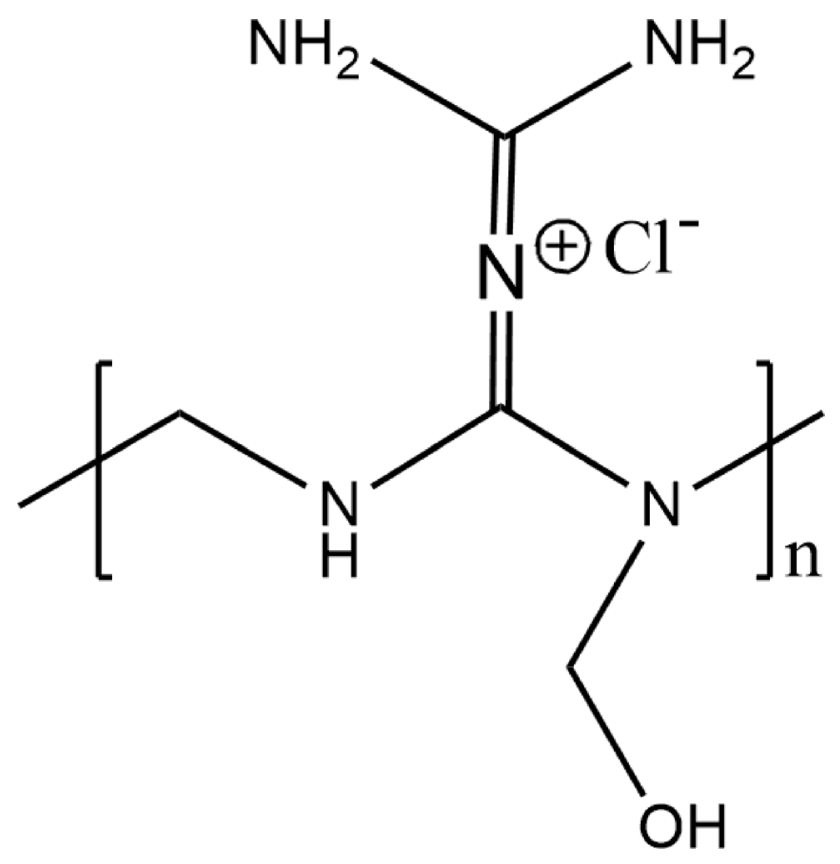

Fig. 1 Structure of poly(methylene-co-cyanoguanidine) pulp and paper, food processing and textile wet processing industries [14, 15], the flocculation of anionically charged particles [16], the adsorption and separation of the rare earth ions [17], and the heterogeneous catalysis for conversion of $\mathrm{CO}_{2}$ into organic carbonates [18]. Interestingly, PMCG polycation has also been applied for preparation of the polyelectrolyte complex-based microcapsules used for immunoprotection of transplanted islets of Langerhans in diabetes treatment [19-23].

From the agricultural point of view, four nitrogen atoms of cyanoguanidine (also known as dicyandiamide, DCD) in each repeating unit (Fig. 1) potentially offer efficient nitrogen nutrition for plants when introduced into the soil. During incubation of this polymer in the soil, DCD as the breakdown product of PMCG may be released to the soil providing two advantages. On one hand, DCD represents one of the most attractive nitrification inhibitors that are used as a tool to reduce nitrogen losses, thus limiting the adverse environmental impact. DCD suppresses the conversion of the relatively immobile mineral form of nitrogen ammonium $\left(\mathrm{NH}_{4}{ }^{+}\right)$cation into highly mobile $\mathrm{NO}_{3}{ }^{-}$anion, and subsequently minimizes the emission of $\mathrm{N}_{2} \mathrm{O}$ [24-29]. On the other hand, the susceptibility of DCD to biodegradation via guanyl urea, guanidine, and urea to yield carbon dioxide and ammonium makes it an excellent source of nitrogen nutrient for plants [30,31]. Thus, considering the chemical composition of PMCG, we found highly interesting to evaluate its impact on the plants growth toward the agricultural purposes. Till now, there are very few reports related to using a polymer by itself as the nitrogen source, i.e. as the polymeric fertilizer, with the potential to slowly release nitrogen that can be metabolized by plants. As an example, De Varennes et al. examined the stimulation effect of polyacrylates neutralized with $\mathrm{NH}_{4}{ }^{+}$ions on ryegrass growth and development [32] and, recently, Hrdlička et al. demonstrated a different sphytotoxicological effect of selected poly(2-oxazoline)s on the growth of Sinapis alba [33].

The aim of this study was to investigate the potential of PMCG during its 6-month incubation in the soil to act as a polymeric fertilizer for monocotyledonous oat (Avena sativa) and dicotyledonous radish (Raphanus sativus L.) model plants recommended by the OECD 208 guidelines.

\section{Experimental}

\section{Materials}

Poly(methylene-co-cyanoguanidine) hydrochloride (PMCG) was supplied by Scientific Polymer Products, Inc. (Ontario, NY, USA) as a ca $35 \%$ aqueous solution and was freezedried before use. Concentrated sulphuric acid, 96\%, hydrochloric acid $0.1 \mathrm{M}$ standard, Tashiro indicator were 
purchased from POCH, Poland. Hydrogen peroxide, $30 \%$, copper sulphate, potassium sulphate, sodium hydroxide, and boric acid were purchased from Chempur, Poland.

\section{Incubation of Poly(methylene-co-cyanoguanidine) in Soil}

The polypropylene pots of diameter $90 \mathrm{~mm}$ and of capacity $300 \mathrm{ml}$ were filled with the control soil or the soil loaded with PMCG. The appropriate PMCG amounts of 5, 25, 125, 250 , and $500 \mathrm{mg}$ were dissolved in water and added to $250 \mathrm{~g}$ of dried soil, which corresponds to PMCG concentrations of $20,100,500,1000$, and $2000 \mathrm{mg} / \mathrm{kg}$ of soil dry weight (s.d.w.). Next, soil in each pot containing dissolved PMCG was thoroughly mixed and left for a specified period of time of $0,1,3$ and 6 months. All pots were regularly watered every day with the same amount of water $(20 \mathrm{ml})$ in order to maintain uniform soil moisture conditions during the whole experiment of 6 months. After incubation for a given period of time, total nitrogen content, $\mathrm{pH}$, and salinity of soil were determined. Simultaneously, ecotoxicological assessment and plant growth tests were performed after $0,1,3$ and 6 months of incubation of PMCG in soil.

\section{Measurements of Soil pH and Conductivity}

Measurements of soil $\mathrm{pH}$ and conductivity were done according to the Polish standards PN-ISO 10390:1997 and PN-ISO $11265+$ AC1:1997, respectively [34, 35]. The soil acidity during the incubation process was determined in a mixture (soil solution) of a distilled water and the dried soil in a volume ratio 5:1 using a $\mathrm{HI} 9318 \mathrm{pH}$ meter (Hanna Instruments). Conductivity was measured in a mixture containing $20 \mathrm{~g}$ of dried soil and $100 \mathrm{ml}$ of water using an EC 215 conductivity meter (Hanna Instruments).

\section{Determination of Total Nitrogen in Soil and Plants}

Total nitrogen content in the soil and plant leaves was determined by the Kjeldahl procedure, which involved digestion, distillation, and titration steps. The sample was digested in sulfuric acid and hydrogen peroxide with selenium as catalyst, wherein organic nitrogen was converted to ammonium sulfate. The solution was then made alkaline and ammonia was distilled. The evolved ammonia was trapped in boric acid and titrated with standard hydrochloric acid.

Determination of total nitrogen in the soil was performed according to the AOAC Official Method of Analysis [36]. Approximately $5 \mathrm{~g}$ of soil from each pot was grinded and sieved through a fine mesh of $0.25 \mathrm{~mm} .1 \mathrm{~g}$ of sieved soil was weighed with accuracy of $0.01 \mathrm{~g}$, placed in a commercial digestion tube (Kjeldahl flask), and $2.5 \mathrm{ml}$ of digestion mixture (concentrated sulphuric acid with selenium
$3.5 \mathrm{~g} / 1000 \mathrm{ml}$ ) was added. Next, 3 aliquots of $1 \mathrm{ml} \mathrm{30 \%}$ hydrogen peroxide were added to each Kjeldahl flask. The tubes were placed in the Kjeldahl digestor (Type M-9, WSL, Bytom, Poland) and heated for about $1 \mathrm{~h}$ at temperature of $200{ }^{\circ} \mathrm{C}$. Then the temperature was increased to $330{ }^{\circ} \mathrm{C}$ and the samples were incubated at this temperature for $2 \mathrm{~h}$ until the mixtures became transparent. The digestion residues were cooled and diluted by $50 \mathrm{ml}$ of distilled water. For each batch (all tested samples containing PMCG), 3 blank experiments in the absence of soil were also determined.

Determination of total nitrogen in plants was carried out according to the Polish standard PN-75/A-04018 [37]. $0.5 \mathrm{~g}$ of dried and homogenized shoots from each pot $(3$ replicates) was weighted and placed in Kjeldahl flask. Next, potassium sulphate $(4.3 \mathrm{~g})$, copper sulphate $(0.2 \mathrm{~g})$, and $96 \%$ sulphuric acid $(9 \mathrm{ml})$ were added. The tubes were placed in the Kjeldahl digestor and treated exactly as the soil samples. Also here, three blank experiments in the absence of plants were determined for each batch.

Next, both soil and plant samples were treated by a distillation procedure. $20 \mathrm{ml}$ of $38 \% \mathrm{NaOH}$ were added to the digestion tube. The tube content was distilled for about 10 min using a steam distillation unit (Type MR-1, WSL, Bytom, Poland). The evolved ammonia was absorbed in $20 \mathrm{ml}$ of $1 \%$ boric acid used as the indicator solution. Then the distillate was titrated with $0.01 \mathrm{~mol} / \mathrm{l} \mathrm{HCl}$ in the presence of Tashiro's indicator until the colour changed from green to pink. All the titrations were performed at room temperature in triplicate. The percentage of total nitrogen content was calculated according to Eq. (1):

$\% N=\frac{a-b}{s} \times M \times 1.4 \times m c f$

where $a$ is the $\mathrm{HCl}$ solution volume required for the sample titration $(\mathrm{ml}), b$ is the $\mathrm{HCl}$ solution volume required for titration of blank sample $(\mathrm{ml}), s$ is the air-dried sample weight (g), $M$ is molarity of $\mathrm{HCl}$ solution, the factor of 1.4 corresponds to the atomic weight of nitrogen multiplied by $100 \%$, and $m c f$ is the moisture correction factor.

\section{Plant Growth Test}

The plant growth test in the presence of PMCG was performed under the laboratory conditions following the OECD 208 Guideline Terrestrial Plants Growth Test for oat (Avena sativa), a monocotyledonous plant, and for radish (Raphanus sativus L.), a dicotyledonous plant [38]. The granulometric composition of soil equaled to $77 \%$ of sand, $19 \%$ of dust and loam, the organic carbon content of approximately $1.8 \%$, with the active acidity value 5.9 (concentration of $\mathrm{H}^{+}$in soil solution).

Each PMCG concentration was tested in triplicate for both plants, i.e. using 3 pots for oat and 3 pots for radish. 
After specific periods of time, i.e. 0, 1, 3 and 6 months, twenty seeds of each of the plant were sown into the soil. Seeds originated from the same source. Plants were grown for 14 days under controlled conditions including a constant humidity content at the level required for the plants of $70 \%$ field water capacity, a temperature of $22 \pm 2{ }^{\circ} \mathrm{C}$, and a constant light intensity of $7000 \mathrm{~lx}$ maintained during a day in the system for $16 \mathrm{~h} /$ day and $8 \mathrm{~h} / \mathrm{night}$.

The effect of PMCG on the plant growth was based on comparing the germination, dry weight of control plants sprouts (seedlings) with germination, and of dry and fresh plants sprouts grown in the soil without (control) and with PMCG added to the soil at a given concentration. The height of shoots and the length of roots were measured as described previously [39]. The length of plants is defined as the length the tip of the longest leaf to the base of culms, while root length is measured from the tip of the longest root to the root-shoot junction. The growth inhibition (\% GI) ratio of shoots, roots and fresh matter (yield) was calculated according to Eq. (2):

$\mathrm{GI} \%=\frac{C p-T p}{C p} \times 100 \%$

where $C_{\mathrm{p}}$ is the height/length of shoot/roots $(\mathrm{cm})$ in control plants, $T_{\mathrm{p}}$ is the height/length of shoot/roots $(\mathrm{cm})$ in tested plants. In case of fresh matter, $C_{\mathrm{p}}$ is the weight of yield $(\mathrm{g})$ in control plants and $T_{\mathrm{p}}$ is the weight of yield $(\mathrm{g})$ in tested plants.

The dry weights of tested plants were measured after drying at $75{ }^{\circ} \mathrm{C}$ until the constant weight and obtained values were compared to dry weight of untreated plants. The visual evaluation of any type of damage of tested plants, such as their growth inhibition, chlorosis, and necrosis was documented by a digital photography.

\section{Pigment Assay}

The content of photosynthetic pigments was determined according to the method reported by Oren et al. [40]. Fresh leaves $(200 \mathrm{mg})$ were thoroughly homogenized in $20 \mathrm{ml}$ of $80 \%$ acetone in water in a cooled mortar, and then centrifuged. The contents of chlorophyll a, chlorophyll $\mathrm{b}$ and carotenoids, expressed in $\mathrm{mg} / \mathrm{g}$ of dry weight, were calculated based on the absorbance at wavelengths of 470, 647 and $664 \mathrm{~nm}$, respectively.

\section{Microtox $^{\circledast}$ Acute Toxicity Assay}

This test exposes luminescent organisms in Microtox ${ }^{\circledR}$ Acute Reagent to aqueous samples, and measures the increase or decrease in light output by the test organisms. The method is based on the analysis of light emission reduction of luminescent bacteria (Allivibrio fischeri) under toxic stress. The tests were carried out in a Microtox ${ }^{\circledR}$ M500 analyzer according to the Microtox ${ }^{\circledR}$ manual [41]. All materials and reagents were purchased from Modern Water Inc. (New Castle, DE, USA). The toxicity was determined by using the marine luminescent bacteria $A$. fischeri, naturally adapted to a saline environment. The lyophilized bacteria were rehydrated with a reconstitution solution to provide a ready-touse suspension of organisms. The test system measures the light output of the luminescent bacteria after they were exposed to a sample and compares it to the light output of a control (reagent blank) that contains no sample. A difference in light output between the sample and the control is attributed to the effect of the sample on the organisms.

\section{Microtox ${ }^{\circledR}$ Solid-Phase Test}

This test was used to determine an acute toxicity of soil containing PMCG after 1, 3 and 6 months of PMCG incubation in the soil. The procedure was adopted from Doe et al. that assesses the toxicity effect of the solid fraction of a sample, in the form of an aqueous suspension, on bacteria present in this suspension [42]. Bacteria were regenerated with $1 \mathrm{ml}$ of $0.01 \%$ reconstitution solution and placed in the reagent well of the Microtox ${ }^{\circledR}$. A suspension prepared by dispersing $7 \mathrm{~g}$ of the soil in $35 \mathrm{ml}$ of a solid phase diluent $(3.5 \% \mathrm{NaCl})$ was stirred using a magnetic stirrer for $10 \mathrm{~min}$. A series of dilutions were made and bacteria (approx. $1 \times 10^{6} \mathrm{cell} / \mathrm{ml}$ per assay) were exposed to these dilutions and to a blank 3.5\% $\mathrm{NaCl}$ solution for $20 \mathrm{~min}$. Next, suspensions were filtered and after $5 \mathrm{~min}$ the light output of supernatants containing exposed bacteria was measured with a Microtox ${ }^{\circledR}$ Analyzer 500. The inhibition was determined as the concentration of a compound loaded to the soil $(\mathrm{mg} / \mathrm{l})$ that caused a $50 \%$ reduction in the light emitted by the bacteria $\left(E C_{50}\right)$. The 95\% confidence intervals were determined using the MicrotoxOmni software.

\section{Microtox $^{\circledast} \mathbf{8 1 . 9 \%}$ Basic Test}

This test was implemented to determine the acute toxicity of PMCG. Allivibrio fischeri bacteria in the freeze-dried form were activated prior to use by a reconstitution solution. Since this bacteria is a marine organism, the osmotic pressure of samples was adjusted using a concentrated salt solution ( $22 \% \mathrm{NaCl}$ in deionized water) to achieve $2 \%$ salinity. The acute toxicity endpoint was determined for 15 and $30 \mathrm{~min}$ as the $E C_{50}$ values evaluated using the $81.9 \%$ basic test selected by the MicrotoxOmni software. The corresponding 95\% confidence intervals were based on regression analysis and were calculated automatically by the MicrotoxOmni software. 


\section{Ostracod Test Kit}

The ecotoxicity of PMCG was performed by a short-term contact test using Ostracodtoxkit $\mathrm{F}^{\mathrm{TM}}$ provided by MicroBiotests Inc. (Gent, Belgium). This direct soil contact bioassay was performed in multi-well test plates using neonates of the benthic ostracod crustacean Heterocypris incongruens hatched from cysts [43]. After 6 days of contact with the soil, the percentage mortality and the growth of the crustaceans were determined and compared to the results obtained in a soil non-treated with PMCG used as a reference soil. According to the manual of Ostracodtoxkit test, the cysts (H. incongruens) were transferred into a Petri dish, filled with $10 \mathrm{ml}$ tap water, used as a reconstituted water, and were incubated at $25^{\circ} \mathrm{C}$ for $52 \mathrm{~h}$ under continuous illumination of approx. 3000-4000 lx. After $48 \mathrm{~h}$ of cysts incubation, prefeeding of the freshly hatched ostracods was performed with algae (spirulina-powder) provided in the test kit. Next, after hatching and before feeding with algal food suspension, the measurements of ostracod neonates length were done. Algae (Selenastrum capricornutum) used as a feed in the test plate was reconstituted according to the manufacturer's instructions. Each well of a test plate was filled in the following order: $2 \mathrm{ml}$ tap water, $2500 \mu \mathrm{l}$ of soil PMCG treated and nontreated (blank) for the comparison, $2 \mathrm{ml}$ already prepared algal suspension, 10 ostracods. The test plates were covered with Parafilm ${ }^{\circledR}$ and closed by a lid. Then multi-well plates were incubated at $25^{\circ} \mathrm{C}$ in the dark for 6 days. The ostracods were then recovered from the multi-well plates to determine the percentage mortality. To calculate the growth inhibition of survived organisms, their length measurements were also done. The mortality of test organisms was determined in six replicates. The length measurements were performed by means of a micrometric strip placed at the bottom of a glass microscope plate. Percentage growth inhibition (GI \%) of $H$. incongruens in the test sediment was calculated according to Eq. (3):

$\mathrm{GI} \%=100-\left(\frac{L t s}{\text { Lrs }} \times 100\right)$

where $L_{\mathrm{ts}}$ is the length of living crustaceans in the tested soil and $L_{\mathrm{rs}}$ is the length of living crustaceans in the reference soil.

\section{Statistical Analysis}

The significance of the obtained results was evaluated using the analysis of variance (ANOVA). The least significant difference (LSD) values at a confidence level of $95 \%$ were computed using the Tukey test. Moreover, the mean standard deviation were determined and plotted in diagrams. Statistical analysis was performed with STATISTICA 13.3 software.

\section{Results and Discussion}

In plants, nitrogen is responsible for rapid early growth and promotes the growth and development of leaves, stem, and other vegetative parts. On the other side, excessive amount of nitrogen has negative effect on the plant growth and development, resulting in yield reduction [44]. Nitrogen toxicity occurs usually as a result of the application of excessive amounts of fertilizer and harmful symptoms may be a result of plants uptaking too much of nitrogen in any form. Plants suffering from nitrogen overdose may be stunted, but usually they are very tall and spindly.

Table 1 provides the information on the effect of PMCG concentration contained in the soil on shoot height, root length, and fresh matter yield of the tested plants. All these parameters are considered as the biomarkers of growth inhibition due to the presence of PMCG.

In this study, the concentration of $2000 \mathrm{mg} / \mathrm{kg}$ of PMCG in the soil caused inhibition of the growth and plan development due to the overdose of PMCG as a fertilizer. These findings are in accordance with existing reports related to nitrogen fertilization for oat and radish plants. Increasing the concentration of available nitrogen up to a critical dose promotes grain yield, growth, development, and quality of both plants [45, 46]. From the agrochemical point of view, results obtained in the plant growth test conducted in the presence of PMCG in the soil showed interesting and promising results. All negative values shown in Table 1, that were calculated according to Eq. (2), indicate that tested parameters were higher when compared to the plants grown in the absence of PMCG (control). Hence, PMCG promotes the growth of these plants under given conditions.

\section{Shoot Height}

PMCG at the concentration of up to $1000 \mathrm{mg} / \mathrm{kg}$ of soil revealed a growth promotion effect on shoot height of oat and radish seedlings. The maximum effect is seen for concentrations of 100 and $500 \mathrm{mg} / \mathrm{kg}$ of soil while this effect is weakened at the concentration of $1000 \mathrm{mg} / \mathrm{kg}$ of soil (Table 1; Figs. 2, 3). The growth promotion is directly proportional to the time of PMCG incubation in the soil. The PMCG concentration of $2000 \mathrm{mg} / \mathrm{kg}$ of soil inhibited the radish shoot height and this effect increased with the time of PMCG incubation in the soil. In the case of oat, this PMCG concentration caused the inhibition effect only after 0 and 1 month of PMCG incubation, while after 3 and 6 months of PMCG incubation a slight growth promotion effect was observed. 
Table 1 Effect of PMCG on the shoot height, root length and fresh matter of oat and radish sprouts (mean \pm SD) determined after 14 days of growth in the soil containing different amounts of PMCG present in the soil for a different period

\begin{tabular}{|c|c|c|c|c|c|c|c|c|}
\hline \multicolumn{9}{|c|}{ Inhibition biomarkers [\%] } \\
\hline \multirow{2}{*}{$\begin{array}{l}\text { PMCG conc. } \\
\mathrm{mg} / \mathrm{kg} \text { of s.d.w. }\end{array}$} & \multicolumn{4}{|l|}{ Oat } & \multicolumn{4}{|l|}{ Radish } \\
\hline & 0 & 1 month & 3 months & 6 months & 0 & 1 month & 3 months & 6 months \\
\hline \multicolumn{9}{|l|}{ Shoot height } \\
\hline 20 & $-1.6 \pm 1.3$ & $-1.6 \pm 1.8$ & $-10.9 \pm 0.3$ & $-9.7 \pm 1.6$ & $-2.5 \pm 1.4$ & $-10.2 \pm 0.2$ & $-15.7 \pm 1.7$ & $-9.8 \pm 3.3$ \\
\hline 100 & $-3.8 \pm 0.8$ & $-3.8 \pm 0.4$ & $-22.5 \pm 0.2$ & $-18.7 \pm 0.6$ & $-4.0 \pm 0.0$ & $-16.4 \pm 0.5$ & $-22.8 \pm 0.7$ & $-12.3 \pm 1$ \\
\hline 500 & $-9.0 \pm 0.8$ & $-5.5 \pm 1.1$ & $-17.5 \pm 0.1$ & $-20.9 \pm 1.5$ & $-4.1 \pm 0.3$ & $-16.6 \pm 0.1$ & $-22.6 \pm 0.6$ & $-21.5 \pm 1.5$ \\
\hline 1000 & $-2.9 \pm 1.4$ & $-1.2 \pm 0.8$ & $-12.7 \pm 0.8$ & $-20.4 \pm 0.7$ & $-4.7 \pm 0.5$ & $-6.2 \pm 0.2$ & $-8.3 \pm 0.7$ & $-15.3 \pm 0.4$ \\
\hline 2000 & $7.7 \pm 4.4$ & $10.2 \pm 0.6$ & $-5.1 \pm 2.2$ & $-4.8 \pm 3.2$ & $5.7 \pm 2.5$ & $6.0 \pm 2.1$ & $16.4 \pm 4.5$ & $17.5 \pm 5.5$ \\
\hline \multicolumn{9}{|l|}{ Root length } \\
\hline 20 & $0.4 \pm 0.2$ & $-1.2 \pm 0.9$ & $-2.5 \pm 1.0$ & $5.5 \pm 0.0$ & $-0.8 \pm 0.3$ & $-5.3 \pm 1.0$ & $-7.4 \pm 1.3$ & $-0.9 \pm 0.0$ \\
\hline 100 & $17.4 \pm 1.3$ & $10.5 \pm 0.2$ & $8.0 \pm 2.2$ & $16.4 \pm 4.2$ & $0.4 \pm 0.1$ & $-23.5 \pm 4.0$ & $-24.4 \pm 3.2$ & $-25.1 \pm 2.9$ \\
\hline 500 & $27.8 \pm 2.5$ & $18.5 \pm 4.4$ & $21.3 \pm 3.0$ & $20.0 \pm 2.3$ & $0.2 \pm 0.1$ & $-36.6 \pm 3.0$ & $-38.3 \pm 3.5$ & $-21.0 \pm 2.2$ \\
\hline 1000 & $54.3 \pm 2.4$ & $53.2 \pm 4.3$ & $51.5 \pm 1.7$ & $44.8 \pm 2.8$ & $4.4 \pm 1.1$ & $-1.2 \pm 2.9$ & $1.4 \pm 0.0$ & $2.4 \pm 1.1$ \\
\hline 2000 & $75.7 \pm 4.8$ & $74.0 \pm 3.3$ & $70.5 \pm 5.5$ & $64.2 \pm 1.4$ & $7.5 \pm 3.0$ & $7.6 \pm 4.9$ & $8.5 \pm 1.0$ & $15.6 \pm 4.2$ \\
\hline \multicolumn{9}{|l|}{ Fresh matter } \\
\hline 20 & $0.7 \pm 0.9$ & $0.9 \pm 1.9$ & $-4.2 \pm 1.7$ & $-5.6 \pm 1.5$ & $2.9 \pm 1.6$ & $-4.1 \pm 1.9$ & $-9.2 \pm 1.5$ & $-13.5 \pm 0.5$ \\
\hline 100 & $-8.8 \pm 0.2$ & $-7.1 \pm 0.2$ & $-4.7 \pm 0.7$ & $-7.3 \pm 0.0$ & $-18.8 \pm 0.2$ & $-6.0 \pm 0.1$ & $-21.2 \pm 0.4$ & $-38.1 \pm 0.2$ \\
\hline 500 & $-10.3 \pm 0.1$ & $-11.6 \pm 0.0$ & $-14.3 \pm 0.6$ & $-19.8 \pm 0.1$ & $-14.2 \pm 0.2$ & $-27.6 \pm 0.4$ & $-41.3 \pm 0.5$ & $-44.0 \pm 0.3$ \\
\hline 1000 & $1.6 \pm 0.0$ & $1.2 \pm 0.2$ & $-1.3 \pm 0.6$ & $-14.6 \pm 0.3$ & $-25.3 \pm 0.9$ & $-33.8 \pm 0.0$ & $-53.3 \pm 0.4$ & $-54.1 \pm 0.2$ \\
\hline 2000 & $9.7 \pm 1.7$ & $8.5 \pm 0.9$ & $8.1 \pm 0.85$ & $7.5 \pm 1.4$ & $18.4 \pm 1.0$ & $17.7 \pm 1.8$ & $23.0 \pm 2.4$ & $12.0 \pm 2.5$ \\
\hline
\end{tabular}

These values were determined by Eq. (2) and represent the percentage of growth inhibition for a tested parameter compared to the control. Negative values mean that examined parameter was higher (promoted growth) compared to the control plants

\section{Root Length}

The impact of PMCG on plant roots differed depending on tested plant (Table 1; Figs. 4, 5). The root growth inhibition for both tested plants was dependent on the PMCG concentration with only minor dependence on the time of incubation. The increased concentration of PMCG in soil caused gradual growth inhibition of oat roots reaching the value of $76 \%$ at the highest PMCG concentration of $2000 \mathrm{mg} / \mathrm{kg}$ of soil. In contrast, the radish roots were found to be more resistant to the presence of PMCG in soil. At the highest concentration of PMCG in soil $(2000 \mathrm{mg} / \mathrm{kg})$ after 0,1 and 3 months of PMCG incubation in the soil, the inhibition level was $8 \%$ and increased to $16 \%$ after 6 months of PMCG incubation. In addition, the PMCG concentrations of 100 and $500 \mathrm{mg} / \mathrm{kg}$ promoted the growth of radish roots after 1 , 3 and 6 months of PMCG incubation. These results highlight that the oat is significantly a more sensitive plant to the presence of PMCG in the soil than radish.

\section{Fresh Matter}

The fresh matter yield values for both tested plants was both time and PMCG concentration dependent (Table 1; Fig. 2, 3). Increasing the concentration of PMCG in the soil up to
500 and $1000 \mathrm{mg} / \mathrm{kg}$ promoted the fresh matter development for both oat and radish. The fresh matter promotion effect was higher for radish than for oat that, for instance, the GI \% values were $-15 \%$ and $-54 \%$ for oat and radish, respectively, for PMCG concentration of $1000 \mathrm{mg} / \mathrm{kg}$ after 6 months of PMCG incubation in the soil. Only the highest concentration of PMCG of $2000 \mathrm{mg} / \mathrm{kg}$ significantly inhibited the fresh matter development. These data also indicate that the time of incubation plays a role in development of the fresh matter for both plants, which can be related to the PMCG breakdown products released into the soil within the time of incubation. In summary, a crucial outcome of this experiment is that the incubation of PMCG in the soil during at least 6 months improves the growth and development of green parts of both the tested plants.

The obtained results related to the growth inhibition and promotion effects of PMCG on shoot height, root length and fresh matter yield of tested plants show that the concentration of $500 \mathrm{mg} / \mathrm{kg}$ of PMCG in the soil may be considered as the optimal concentration for the promotion of growth and development of oat and radish green parts. In more details, during the first months the fresh matter of oat and radish was about $10 \%$ and $14 \%$ higher than for control plants. These values gradually increased and after 6 months of PMCG incubation in the soil they 
Fig. 2 Photographs of selected oat seedlings at the 14th day growing in the presence of various PMCG concentrations in the soil
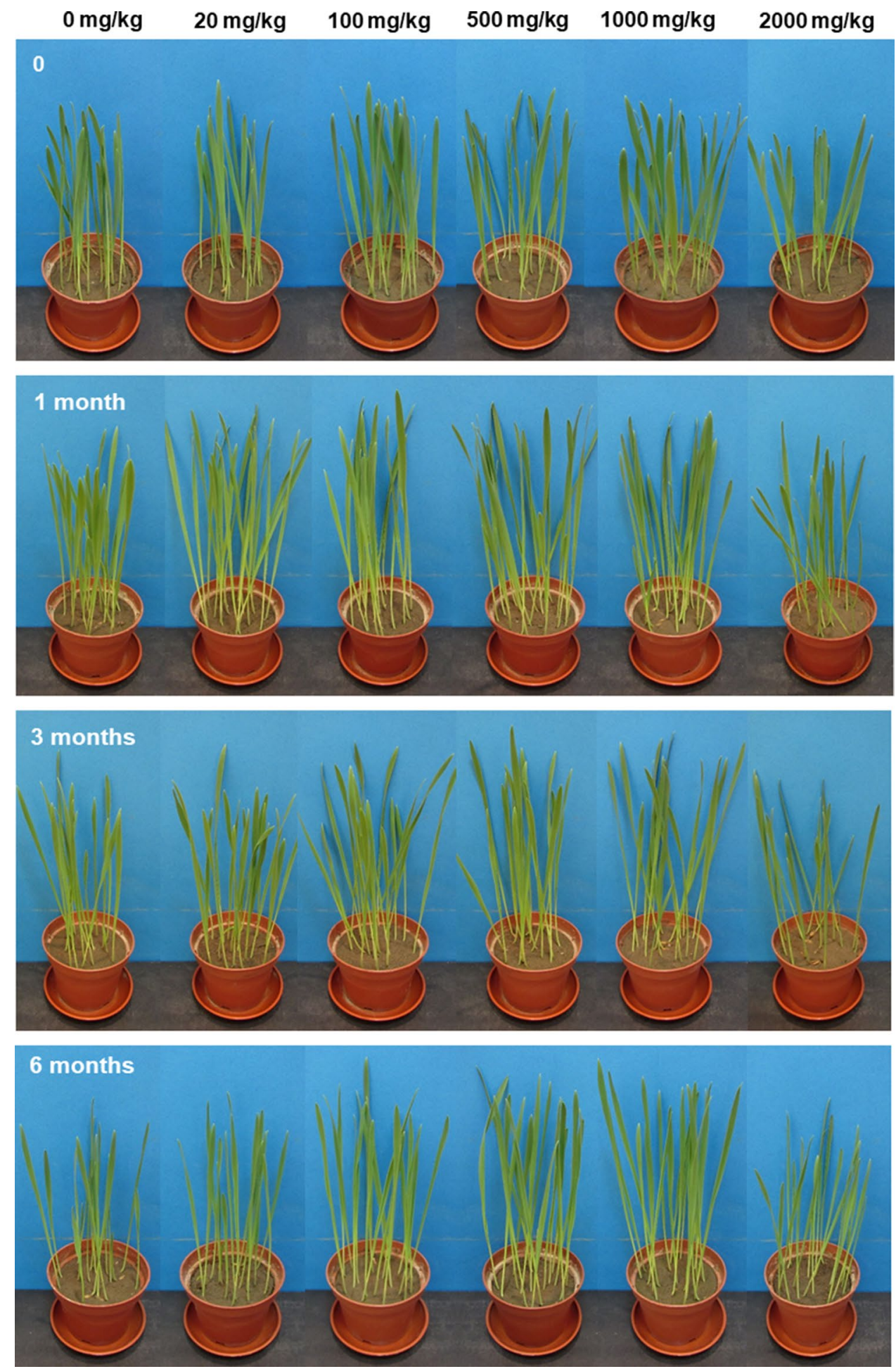

reached $20 \%$ and $44 \%$ for oat and radish, respectively, i.e., approximately two and three times higher than the baseline values. A similar tendency was revealed for the shoot height of both the examined plants. The presence of PMCG at a concentration $500 \mathrm{mg} / \mathrm{kg}$ of the soil also caused a gradual improvement of shoot growth (9\% at the time zero up to $21 \%$ after 6 months for oat, and $4 \%$ at the time zero up to $21 \%$ after 6 months for radish). In other words, more than two and five times higher shoot growth was seen for oat and radish, respectively, after 6 months of the PMCG incubation in the soil compared to the values in the beginning of experiment. 
Fig. 3 Photographs of selected radish sprouts at the 14 th day growing in the presence of various PMCG concentrations in the soil
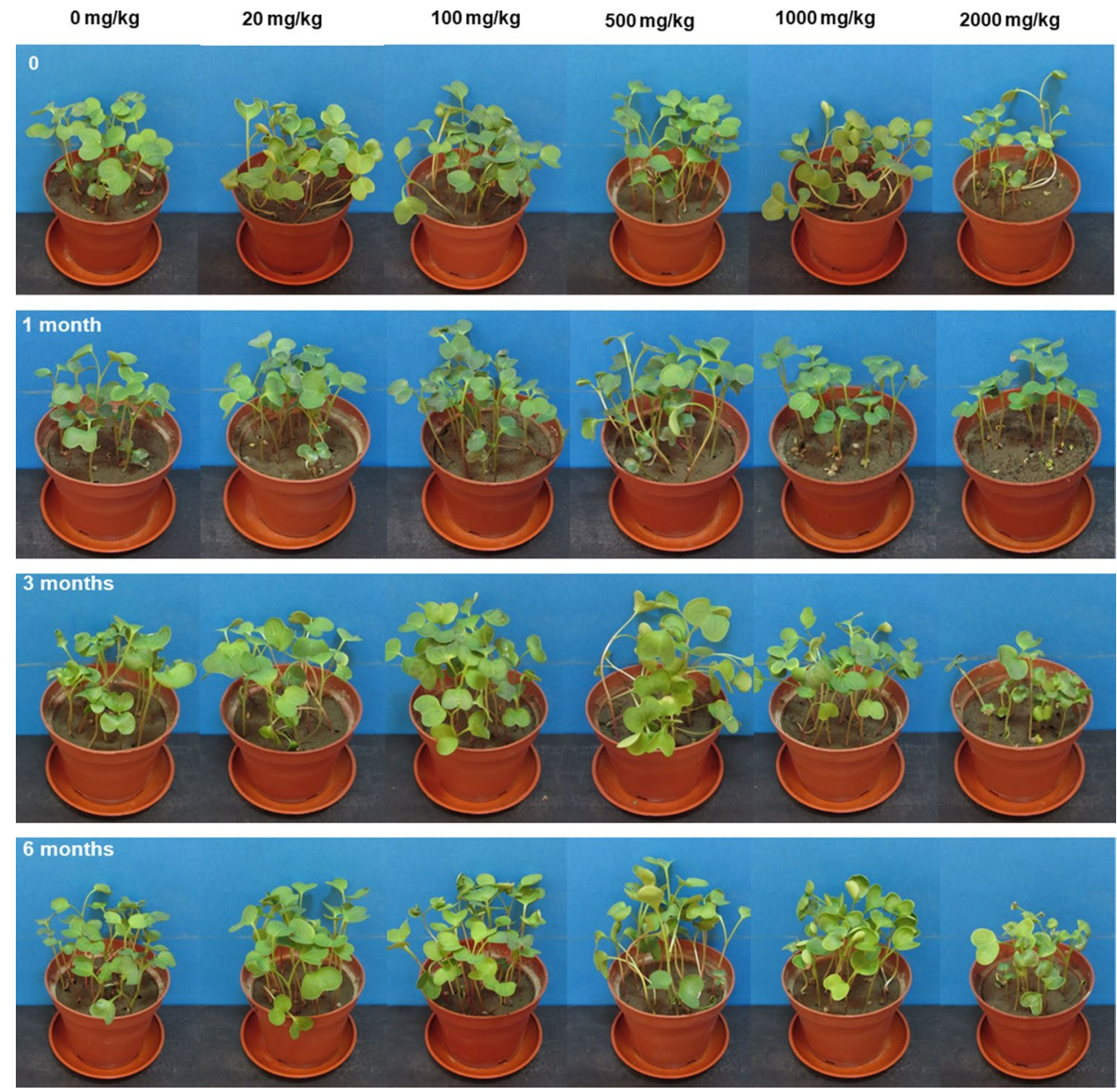

\section{Total Nitrogen Content in the Green Part of Plants and in the Soil}

Figure 6 shows the data related to determination of total nitrogen content in the soil and plants. As expected, increasing the concentration of PMCG in the soil resulted in an increased total nitrogen content in the soil as well as in green parts of oat and radish. This is considered as a significant finding, since this demonstrates the long-term effect of PMCG incubated in the soil providing the controlled release of nitrogen. Consequently, this is reflected by the nitrogen accumulation in plants (Fig. 6a, b) resulting in a more extensive growth of green parts in both the tested plants as discussed above (Table 1). Also interestingly, the increased accumulation of nitrogen in plants correlates with its depletion from the soil as a function of incubation time at each PMCG concentration (Fig. 6c, d). The observed stimulation effect of accumulated nitrogen in plants in this study coincides with other reports [10, 47-49]. The nutrient balance in the soil determines the degree of nutrients utilization by plants. The stress conditions and deficiency of nutrients may occur when the soil either does not contain enough nutrients or when it contains too much of them.

\section{Dry Matter}

Figure 7 illustrates that the dry matter yield of plants varied and is dependent on time of incubation, plant species, and PMCG concentration in the soil. For all PMCG incubation times, the dry matter yield for oat was maintained at approximately the same level up to the PMCG concentration of $500 \mathrm{mg} / \mathrm{kg}$ in the soil, and then it started to increase. This data coincides with results obtained by Zhou et al. who reported that the dry matter of oat and wheat increased following the treatment with a nitrogen fertilizer [50]. This is due to nitrogen being a fundamental constituent of many leaf cell components, particularly those associated with the photosynthetic apparatus, including carboxylating enzymes and proteins of cell membranes [51]. Figure 7 shows that the dry matter yield for oat after 1, 3 and 6 months is lower especially at the highest applied concentrations of PMCG, i.e. 1000 and $2000 \mathrm{mg} / \mathrm{kg}$.

Dry matter level of radish was mostly dependent on the time of PMCG incubation. The highest drop of the dry matter yield compared to control plants was observed for radish seedlings after 1 and 3 months. The increase in the PMCG concentration also caused the gradual decrease of 
Fig. 4 Photographs of selected roots of oat developed in the presence of various PMCG concentrations in the soil
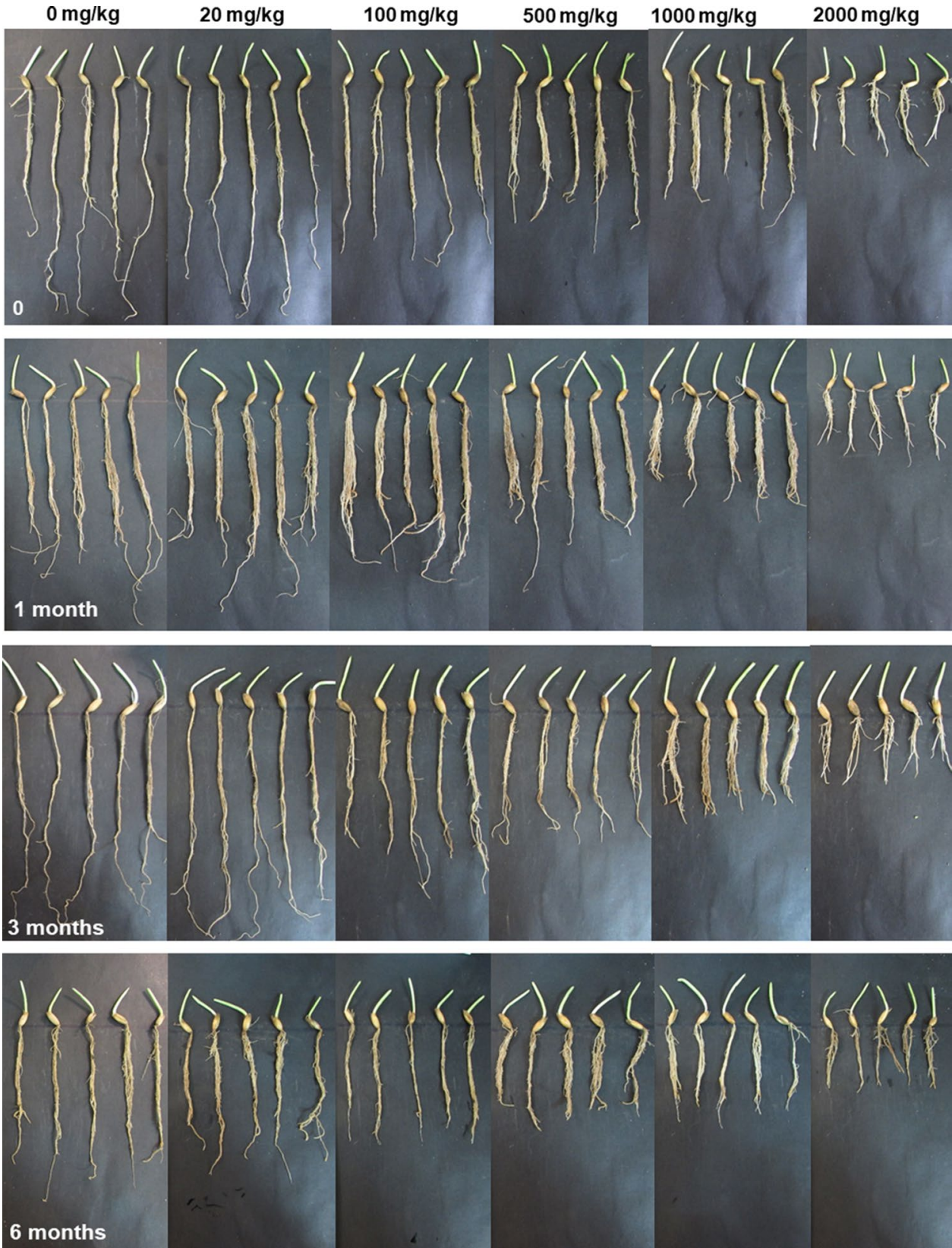

the dry matter yield with exception for the plant growing in the soil wit PMCG incubation for 6 months. The value of dry matter at concentrations of 500, 1000 and $2000 \mathrm{mg} /$ $\mathrm{kg}$ was comparable for radish seedlings at the time of 0 and 6 months, while the dry matter yield at the same concentrations after 1 and 3 months were lower. This corresponds to the fact that the growth and development of a plant strongly depend on the concentration of mineral nutrients available in the soil. The level of dry weight can be correlated with the development of roots. At the beginning of plant growth, roots uptake water and absorb nutrients intensively, being simultaneously exposed to substances presented in the soil and those provided by PMCG. Figures 4 and 5 demonstrate that a higher inhibitory effect upon rising the concentration of PMCG was more evident against roots of monocotyledonous oat than dicotyledonous radish. When the plants are exposed to high PMCG concentrations for longer time, the roots development and growth are obstructed. Consequently, as shown for oat in Fig. 7, the water absorption becomes more difficult and the level of dry matter in the plant starts to increase as shown. On contrary, for radish the root system is well developed allowing for the uptake of water thus decreasing the dry matter yield with time. A reduction in the dry matter of radish treated with increased nitrogen content was also reported by Akoumianakis et al. [52]. De Varenes et al. reported that the dry matter content of plants depends 
Fig. 5 Photographs of selected roots of radish developed in the presence of various PMCG concentrations in the soil
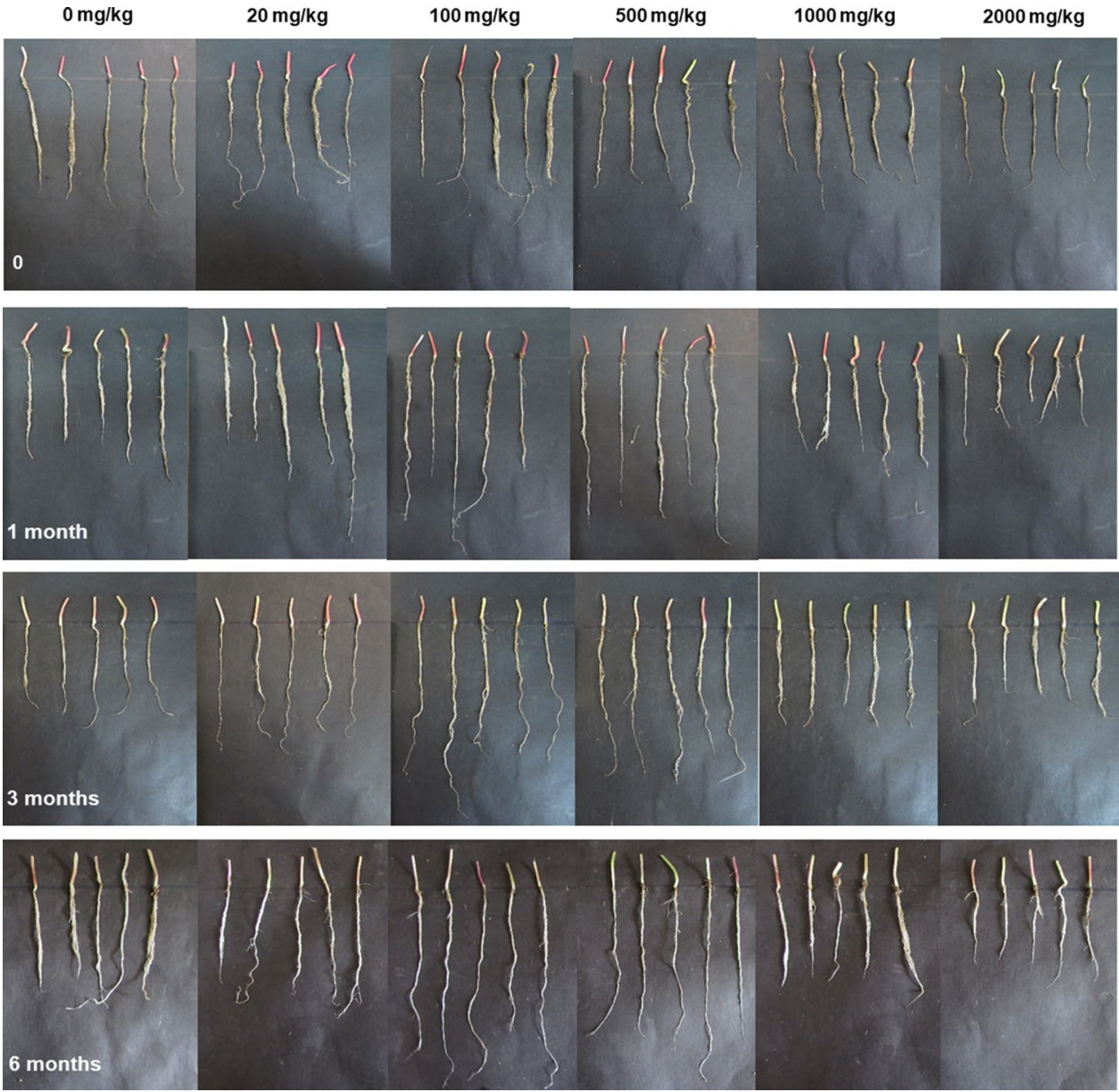

on the presence of polyacrylate polymers in the soil [30]. The incorporation of polyacrylic acid neutralized with $\mathrm{KOH}$, $\mathrm{NaOH}$ and $\mathrm{NH}_{4} \mathrm{OH}$ into the soil resulted in enhanceding the growth of perennial ryegrass.

\section{Seed Germination}

The seed germination depends on several environmental factors such as light, soil temperature, moisture, and nutrients $[53,54]$. In this work, the germination study revealed that even after 6 months of incubation, the presence of PMCG in the soil at a concentration of $2000 \mathrm{mg} / \mathrm{kg}$ did not adversely affect the germination of both oat and radish compared to the untreated plants (Table 2).

The fertilizer has the potential to influence the seed performance, like germinability, dormancy, size, and composition; for instance, high nitrogen levels are reported to promote germination of vegetable seeds $[55,56]$. Other studies report about conflicting effects of a fertilizer on the seed germination. For example, Bremner reported that urea has an adverse effect on germination of wheat, rye and corn seeds [57]. Higher concentrations of fertilizer, including nitrates in the soil, may reduce weed seed germination because of osmotic stress or salt toxicity, similarly to the injury to corn seedlings when fertilizer is placed directly into the seed neighborhood [58].

\section{Total Chlorophyll and Carotenoids}

The increase in the PMCG concentration up to $1000 \mathrm{mg} / \mathrm{kg}$ in the soil resulted in accumulation of pigments chlorophyll and carotenoids in leaves for both types of plants (Figs. 8, 9). The amount of pigments also increased with the PMCG incubation time in the soil. This data corresponds with the increased amount of nitrogen in the soil supplied by PMCG and the photosynthetic efficiency. The nitrogen deficiency is considered as a factor responsible for reduction of chlorophyll and accessory pigments formation [59], whereas the increased amounts of nitrogen in the nutrient solution increases the plant biomass and enhances the accumulation of N, P, K elements, chlorophyll, and carotenoids [60]. In our study, the highest applied PMCG concentration in the soil of $2000 \mathrm{mg} / \mathrm{kg}$ revealed an inhibitory effect on chlorophyll and carotenoid levels in plant leaves. This condition thus represents the situation leading to the excessive accumulation of nitrogen released during incubation of PMCG in 
(a)

$\square 1$ month $\square 3$ months $\square 6$ months

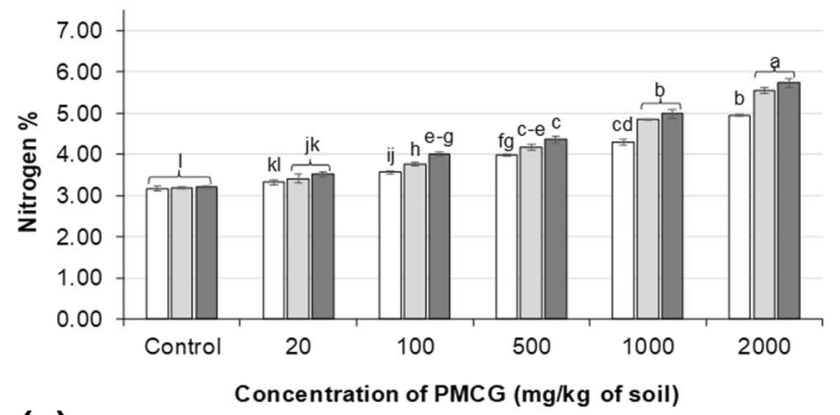

(c)

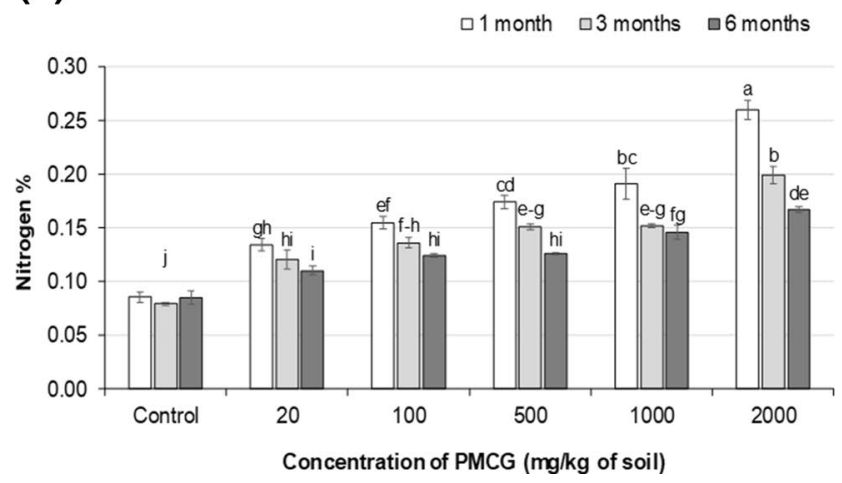

(b)

$\square 1$ month $\square 3$ months $\square 6$ months

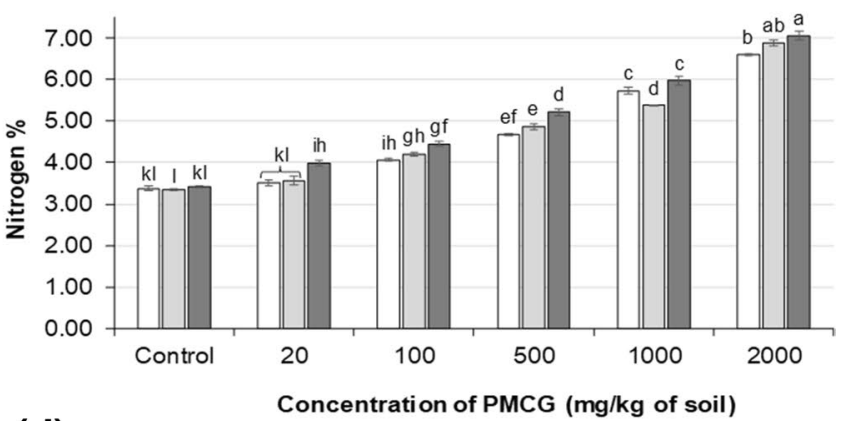

(d)

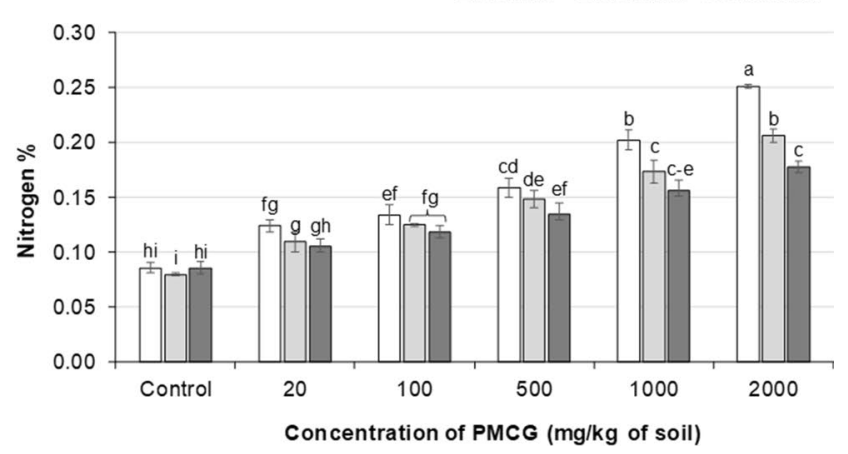

Fig. 6 Percentage of total nitrogen in harvested dried leaves of oat (a), harvested dried leaves of radish (b), soil after oat harvesting (c), and soil after radish harvesting (d). Values denoted by the same letters do not differ statistically at $\mathrm{p}<0.05$

the soil with time. Therefore, the PMCG dose of $2000 \mathrm{mg} / \mathrm{kg}$ is not recommended due to an over-fertilization [44].

In our work, the symptoms of chlorosis and necrosis of treated plants have not been observed (Figs. 2, 3). The plant leaves were of rich green colour without yellowing or whitening of the plant tissue that would indicate the decrease

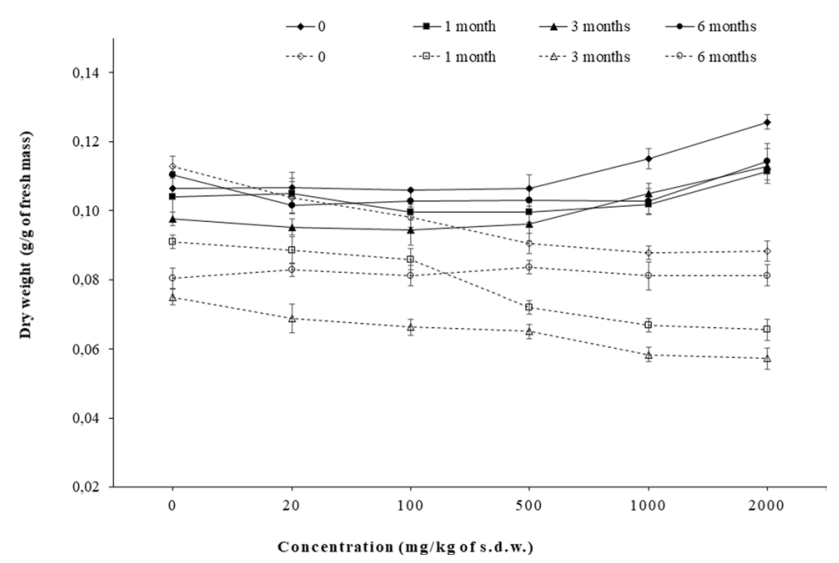

Fig. 7 Dry weight of plants grown in the soil containing different amounts of PMCG incubated in the soil for different time. Solid lines and filled symbols represent the oat dry weight while dotted lines and open symbols represent the radish dry weight of chlorophyll amount resulting from chlorosis and nutrient deficiency.

\section{Soil Acidity and Conductivity}

The soil acidity is one of the most important factors affecting the crop production. The soil $\mathrm{pH}$ influences many chemical and biological reactions that control plant nutrient availability and the toxicity of some elements dissolved in the soil solution [61]. Since most mineral nutrients are readily available to plants and are uptaken through roots directly from soil solution, the actual acidity of the soil was determined as the indicator of changes during the PMCG incubation in the soil (Fig. 10a).

Overall, the soil is slightly acidic with the $\mathrm{pH}$ ranging between the values of 5.5 and 6.1 for all the experiments in this study, with the pH of 5.9 for the PMCG non-treated soil. The addition of PMCG slightly increases the soil acidity, which is proportional to the PMCG content in the soil. The $\mathrm{pH}$ of the soil increases with time of PMCG incubation and after 3 months the acidity was almost at the same level for all the concentrations at the level of non-treated soil. After 6 months and the PMCG concentrations $\leq 500 \mathrm{mg} / \mathrm{kg}$, the acidity of soil is even lower than the control while the 
Table 2 Average values (mean of three replicates) referring to germination of oat and radish seeds germinated in the soil treated with PMCG

\begin{tabular}{|c|c|c|c|c|}
\hline \multirow[t]{2}{*}{$\begin{array}{l}\text { PMCG concentration } \\
\text { in soil }(\mathrm{mg} / \mathrm{kg})\end{array}$} & \multicolumn{2}{|c|}{$\begin{array}{l}\text { Number of emerged } \\
\text { seedlings }\end{array}$} & \multicolumn{2}{|c|}{ Germination $(\%)$} \\
\hline & Oat & Radish & Oat & Radish \\
\hline \multicolumn{5}{|l|}{0} \\
\hline Control & 19 & 19 & 100 & 100 \\
\hline 20 & 19 & 19 & 100 & 100 \\
\hline 100 & 19 & 19 & 100 & 100 \\
\hline 500 & 19 & 18 & 100 & 95 \\
\hline 1000 & 19 & 18 & 100 & 95 \\
\hline 2000 & 19 & 18 & 100 & 95 \\
\hline \multicolumn{5}{|l|}{1 month } \\
\hline Control & 20 & 19 & 100 & 100 \\
\hline 20 & 20 & 18 & 100 & 95 \\
\hline 100 & 20 & 18 & 100 & 95 \\
\hline 500 & 20 & 18 & 100 & 95 \\
\hline 1000 & 19 & 18 & 95 & 95 \\
\hline 2000 & 19 & 18 & 95 & 95 \\
\hline \multicolumn{5}{|l|}{3 months } \\
\hline Control & 19 & 19 & 100 & 100 \\
\hline 20 & 19 & 19 & 100 & 100 \\
\hline 100 & 19 & 19 & 100 & 100 \\
\hline 500 & 19 & 19 & 100 & 100 \\
\hline 1000 & 19 & 19 & 100 & 100 \\
\hline 2000 & 19 & 18 & 100 & 95 \\
\hline \multicolumn{5}{|l|}{6 months } \\
\hline Control & 20 & 19 & 100 & 100 \\
\hline 20 & 19 & 19 & 95 & 100 \\
\hline 100 & 19 & 19 & 95 & 100 \\
\hline 500 & 19 & 18 & 95 & 95 \\
\hline 1000 & 19 & 18 & 95 & 95 \\
\hline \multirow[t]{2}{*}{2000} & 19 & 18 & 95 & 95 \\
\hline & \multicolumn{4}{|c|}{$\mathrm{LSD}=1$} \\
\hline
\end{tabular}

The least significant difference (LSD) is given at the bottom. The percentage of germination refers to the number of emerged plants compared to the control

highest PMCG concentrations resulted in the acidity close to the control.

This may be explained by the fact that cyanoguanidine (DCD), as one of the possible PMCG degradation products, is susceptible to biodegradation via guanyl urea, guanidine, and urea to yield carbon dioxide and ammonium [30, 31]. This DCD biodegradation in the soil takes about 100 days. Hence, it can be assumed that after 3 months of PMCG incubation in the soil, some of the mentioned degradation products are likely released into the soil [62]. Then an increase in the $\mathrm{pH}$ of soil after 1 and 3 months of PMCG incubation may be due to the presence of guanidine and urea in the soil, both exhibiting alkaline properties. A decrease in the
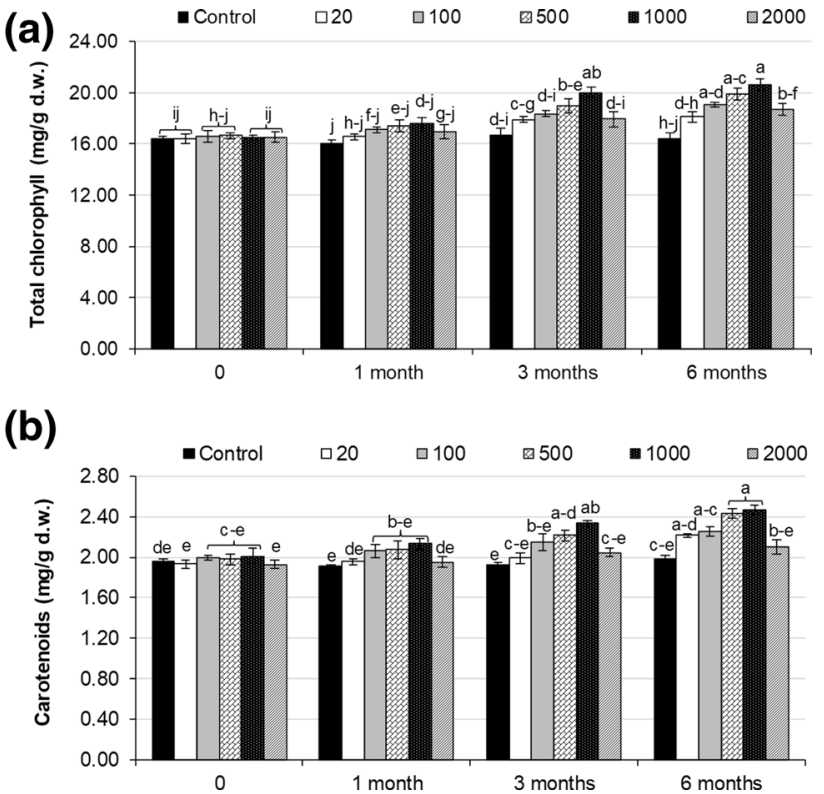

Fig. 8 Effect of the PMCG content and the time of its incubation in the soil on the content of total chlorophyll (a) and carotenoids (b) in oat seedlings. Data are expressed as a mean $\pm S D(n=3)$. Values denoted by the same letters do not differ statistically at $\mathrm{p}<0.05$
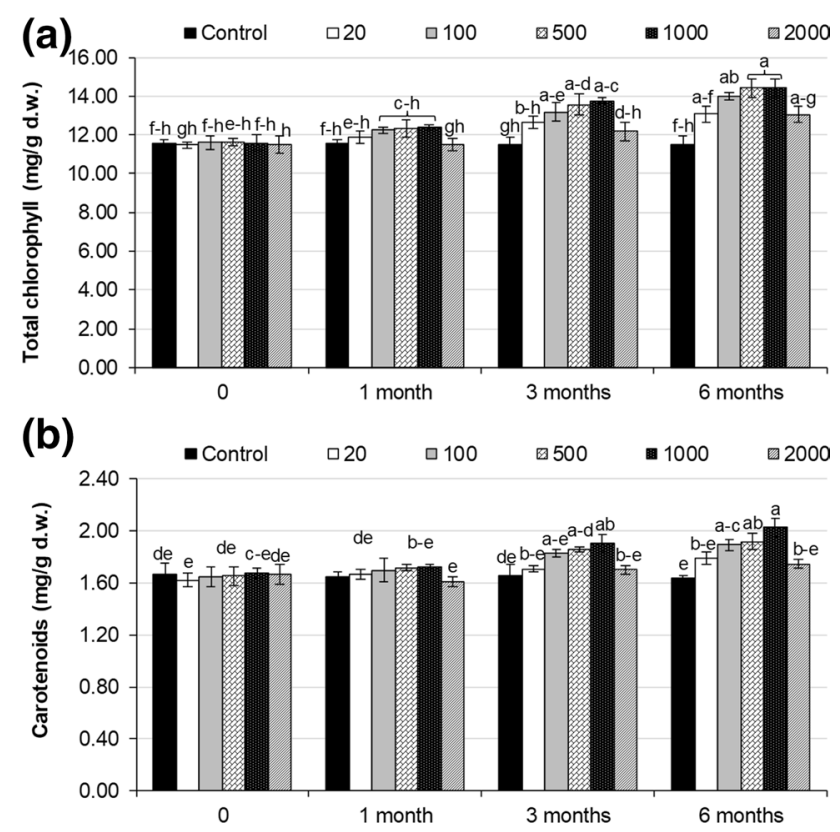

Fig. 9 Effect of the PMCG content and the time of its incubation in the soil on the content of total chlorophyll (a) and carotenoids (b) in radish sprouts. Data are expressed as a mean \pm SD $(n=3)$. Values denoted by the same letters do not differ statistically at $\mathrm{p}<0.05$

soil acidity with increasing the PMCG concentration after 6 months of its incubation in the soil may result from the degradation of DCD into urea or other forms available for plants, such as ammonium ions [24-29, 63, 64]. The use of 
(a)

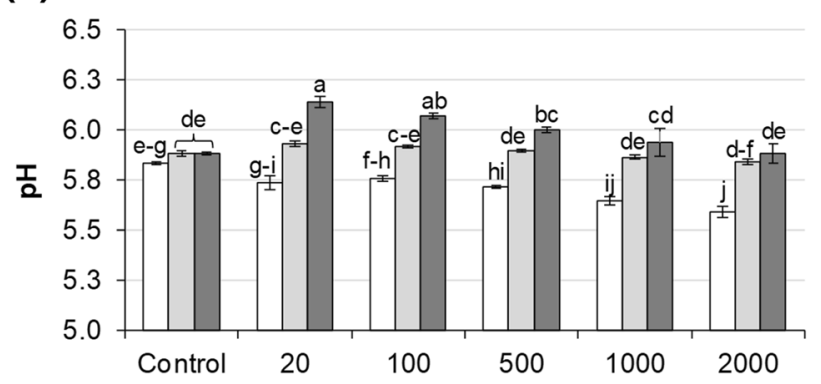

(b)

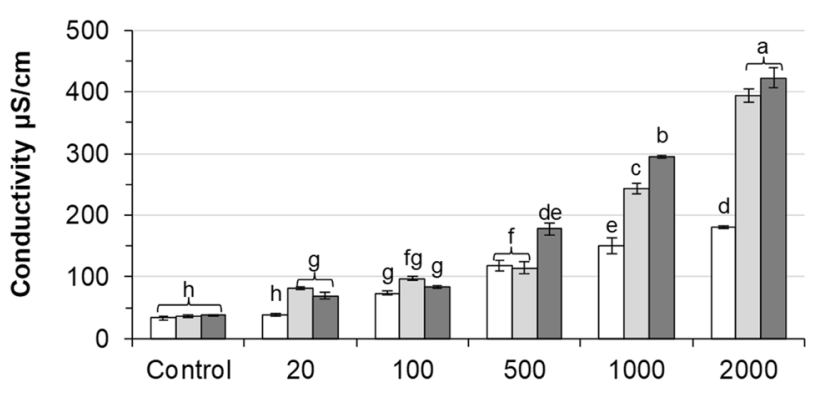

Concentration of PMCG in soil ( $\mathrm{mg} / \mathrm{kg}$ of soil)

Fig. 10 Effect of the PMCG content and the time of its incubation in the soil on $\mathbf{a} \mathrm{pH}$ and $\mathbf{b}$ conductivity of soil. Data are expressed as a mean $\pm \mathrm{SD}(\mathrm{n}=3)$. Values denoted by the same letters do not differ statistically at $\mathrm{p}<0.05$

ammonia or ammoniacal fertilizers in the crop production has been shown to increase the soil acidity, however, some studies also report that there are no significant differences in the soil $\mathrm{pH}$ after treatment with ammonia, ammonium nitrate, and urea $[65,66]$. Additionally, a significant increase of the soil conductivity during the experiment shown in Fig. 10b confirmed the accumulation of dissolved ions in the soil solution. These ions were not specified in this work, nevertheless, they originate from PMCG present in the soil and/or from its degradation products.

The A. fischeri bioluminescence inhibition bioassay is widely used for the monitoring of toxicity due to its advantages such as short test duration, sensitivity, cost-effectiveness, and ease of operation. This bioassay was found to be equally applicable to various types of matrices, including organic and inorganic compounds, metals, wastewater, river water, sewage sludge, landfill leachate, herbicides, treated wastewater, etc. [67]. In our study, the Microtox ${ }^{\circledR}$ test was employed for ecotoxicological evaluation of PMCG and its degradation products released into the soil during its incubation in the soil for 1, 3, and 6 months (Table 3; Fig. 11).

Figure 11 represents the response level, i.e. a relationship between a toxic reaction (the response) and the amount of PMCG (the dose), of A. fischeri to the increased PMCG concentration. According to Hernando et al. the toxicity categories based on the $\mathrm{EC}_{50}$ values are as follows: "very
Table 3 Microtox ${ }^{\circledR} \mathrm{EC}_{50}$ values of PMCG determined via basic and solid phase test after exposure on the luminescent marine bacteria $A$. fischeri with respective $95 \%$ confidence limits (in brackets) obtained in the fit of the data

PMCG basic test $\left(\mathrm{EC}_{50} \mathrm{mg} / \mathrm{l}\right)$

\begin{tabular}{ll}
\hline $5 \min$ & $15 \min$ \\
\hline 224 & 144 \\
$(74$ to 678$)$ & $(93$ to 222$)$ \\
$\mathrm{R}^{2}=0.7187$ & $\mathrm{R}^{2}=0.9401$
\end{tabular}

Solid phase test $\left(\mathrm{EC}_{50} \mathrm{mg} / \mathrm{kg}\right.$ of soil)

Incubation time (months)

\begin{tabular}{lll}
\hline 1 & 3 & 6 \\
\hline 476 & 697 & 978 \\
$(273$ to 829$)$ & $(425$ to 1143$)$ & $(455$ to 2103$)$ \\
$\mathrm{R}^{2}=0.8752$ & $\mathrm{R}^{2}=0.8794$ & $\mathrm{R}^{2}=0.800$ \\
\hline
\end{tabular}

toxic to aquatic organisms" $\left(\mathrm{EC}_{50}<1 \mathrm{mg} / \mathrm{l}\right)$, "toxic" $\left(\mathrm{EC}_{50}\right.$ in the range of $1-10 \mathrm{mg} / \mathrm{l})$, and "harmful" $\left(\mathrm{EC}_{50}\right.$ in the range of $10-100 \mathrm{mg} / \mathrm{l}$ ), which are established in the Directive 93/67/EEC [68]. Following these regulations, the significantly higher $\mathrm{EC}_{50}$ values for PMCG than those defining these three categories, regardless of the type of Microtox ${ }^{\circledR}$ test used, demonstrate that PMCG can be considered as the non-harmful substance to aquatic organisms. EC $_{50}$ values elevated with the time of incubation of PMCG in the soil, which indicates that the PMCG degradation products are even less harmful to A. fischeri than PMCG by itself.

Besides the effect of PMCG on the growth inhibition, the crustacean mortality is the second method used for evaluation of potential toxic effect as indicated by the Ostracodtoxkit F $^{\mathrm{TM}}$ microbiotest. This parameter allows for the evaluation of the sub-lethal toxicity of sediments that in this study is represented by the soil containing PMCG. The growth inhibition was determined by comparing the size of surviving ostracods in the test with the size of ostracods living in the PMCG non-treated soil at the end of the test. The sub-lethal impact of the soil toxic substances is justified only for the systems, which do not cause a high ostracod mortality. According to the manual of Ostracodtoxkit ${ }^{\circledR}$ test, growth inhibition should only be determined for sediments. where mortality was found to be less than $30 \%$ (Table 4). Therefore, the growth inhibition was chosen as a criterion of sub-lethal effects to determine toxicity that does not induce substantial mortality in the test organisms. Hence, the measurements of length of organisms were only performed for the situation when the mortality is lower than $30 \%$.

Soil samples with two PMCG concentrations of 500 and $2000 \mathrm{mg} / \mathrm{kg}$ were selected for the Ostracodtoxkit ${ }^{\circledR}$ test. Obtained results revealed that the percentage in mortality and growth inhibition for $H$. Incongruens depend on the PMCG concentration and time of its incubation in the soil, although there is no an obvious trend in the effect of 


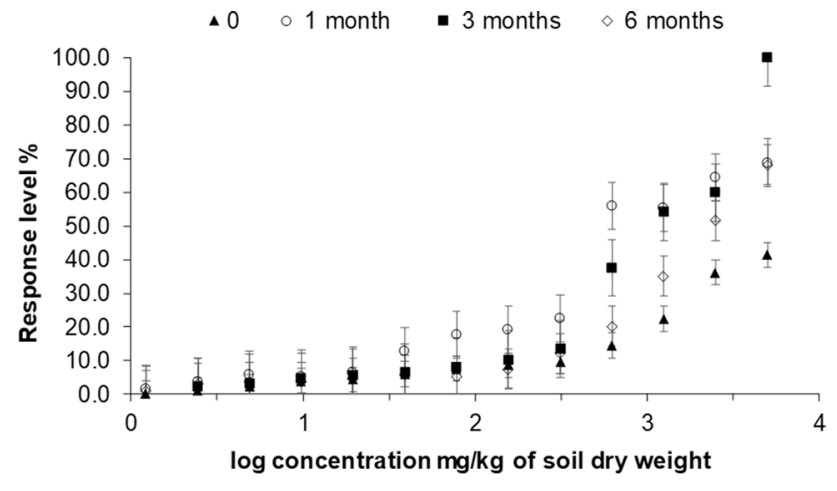

Fig. 11 The $\mathrm{EC}_{50}$ graded dose-response dependence for the PMCG incubated in the soil. Overlapped data markers are plotted by Microtox ${ }^{\circledR}$ Analyzer 500 software. Error bars represent standard deviations $(\mathrm{n}=3)$

incubation time on the crustacean mortality (Table 4). Unexpectedly, the PMCG concentration of $2000 \mathrm{mg} / \mathrm{kg}$ caused lower mortality compared to the PMCG concentration of $500 \mathrm{mg} / \mathrm{kg}$. For both tested concentrations, the highest mortality was noticed after 1 and 6 months of PMCG incubation in the soil. This may be due releasing the most harmful PMCG degradation products to the soil during these periods of time with the impact on survival of ostracods.

A decrease in ostracods mortality after 0 and 1 month of PMCG incubation in the soil is also reflected in the growth promotion of these organisms compared to the control. The PMCG concentration of $2000 \mathrm{mg} / \mathrm{kg}$ caused a significant growth of crustacean after 0 and 1 month reaching 32 and $24 \%$ respectively. Further incubation of PMCG in the soil at this highest PMCG concentration did not affect the growth of ostracods.

Obtained results suggest that the presence of PMCG in the soil, even at the highest tested concentration of $2000 \mathrm{mg} /$ $\mathrm{kg}$, may stimulate the growth of crustaceans especially at the beginning of its incubation in soil (up to 1 month). From the ecotoxicological point of view, this is seen as a great advantage since the PMCG polymer is considered as a nutrient for the soil microorganisms like $H$. incongruens. Moreover, the nitrogen-based PMCG degradation products released into the soil for up to 6 months during the PMCG incubation did not adversely affect the growth of these organisms compared to the control. This is another evidence that PMCG may be successfully used as the nitrogen fertilizer with prolonged activity.

\section{Conclusions}

A suitable management of nitrogen nutrition to optimize yield without any adverse effect on the environment, caused by introduction of excessive amount of fertilizers, is currently the key to ensuring the profitable agricultural production. Poly(methylene-co-cyanoguanidine), PMCG, the cationic oligomer was found as the potential polymer fertilizer that does not require special treatment and can be used as is for the prolonged release of nitrogen in agriculture. Hence, PMCG may be considered as an advantageous alternative to currently used fertilizers with a prolonged release.

Based on the obtained results using monocotyledonous oat (Avena sativa) and dicotyledonous radish (Raphanus sativus L.) selected as model plants, the following conclusions can be drawn from this work:

(1) When incubated in soil, PMCG during the course of the experiment released nitrogen-based degradation products, which promoted growth and development of green parts for both the tested plants.

(2) The application of PMCG in a concentration at and beyond $2000 \mathrm{mg} / \mathrm{kg}$ of the soil dry weight caused overfertilization by the nitrogen nutrient and have negative impact on tested plants.

(3) The ecotoxicological assessment of PMCG against $A$. fischeri and $H$. incongruens revealed that PMCG is not harmful against these organisms. Even more, the highest applied PMCG concentration of $2000 \mathrm{mg} / \mathrm{kg}$ of soil caused the significant growth of crustacean up to 1 month of incubation, which means that PMCG provides nutrition value to these organisms.

In our opinion, from the agricultural and environmental protection point of view, presented results are very promising for application of PMCG as a potential nitrogen fertilizer with prolonged activity. This statement can also be justified by our rough cost estimate indicating that the cost of
Table 4 The percentage values for mortality and growth inhibition of $H$. incongruens in soil containing PMCG at concentrations of 500 and $2000 \mathrm{mg} / \mathrm{kg}$ of the soil dry weight $(n=6)$

\begin{tabular}{|c|c|c|c|c|c|c|c|c|}
\hline \multirow{2}{*}{$\begin{array}{l}\text { PMCG concen- } \\
\text { tration in soil } \\
\text { ( } \mathrm{mg} / \mathrm{kg} \text { of } \\
\text { s.d.w.) }\end{array}$} & \multicolumn{4}{|c|}{ Mortality (\%) } & \multicolumn{4}{|c|}{ Growth inhibition (\%) } \\
\hline & 0 & 1 month & 3 months & 6 months & 0 & 1 month & 3 months & 6 months \\
\hline 500 & $15 \pm 1$ & $25 \pm 1$ & $10 \pm 0$ & $30 \pm 0$ & $15 \pm 4$ & $8 \pm 4$ & $-2 \pm 1$ & $-10 \pm 2$ \\
\hline 2000 & $10 \pm 1$ & $15 \pm 2$ & $5 \pm 1$ & $20 \pm 1$ & $-32 \pm 3$ & $-24 \pm 5$ & $0 \pm 1$ & $2 \pm 1$ \\
\hline
\end{tabular}

Negative values mean that growth of examined crustaceans was higher compared to the organisms nontreated with PMCG 
PMCG for agricultural purposes may be slightly higher, but in the same order of magnitude as is the cost of commercial nitrogen fertilizers.

This study performed under laboratory conditions requires a more detailed investigation in real conditions to confirm the usefulness of PMCG as a fertilizer. However, this work provides fundamental understanding and protocols to be followed in future work using PMCG for agricultural purposes. The future work will also include the study related to degradation mechanism of PMCG in the soil and determination of its degradation products in water and in soil. This will allow to precisely identify which intermediates play a crucial role as a nitrogen nutrition for plants.

Acknowledgements IL would like to acknowledge the support by the Slovak Research and Development Agency under Contract Number APVV-14-858. Dr. Vladimir Raus from the Institute of Macromolecular Chemistry of the Czech Academy of Sciences in Prague, Czech republic, for discussion on chemistry and applications of PMCG polycation.

Open Access This article is distributed under the terms of the Creative Commons Attribution 4.0 International License (http://creativeco mmons.org/licenses/by/4.0/), which permits unrestricted use, distribution, and reproduction in any medium, provided you give appropriate credit to the original author(s) and the source, provide a link to the Creative Commons license, and indicate if changes were made.

\section{References}

1. Mosier AR, Bleken MA, Chaiwanakupt P, Ellis EC, Freney JR, Howarth RB, Matson PA, Minami K, Naylor R, Weeks KN, Zhu ZL (2001) Biogeochem 52:281

2. http://faostat.fao.org/

3. Bashir MT, Ali S, Ghauri M, Adris A, Harun R (2013) Asian J Microbiol Biotech Environ Sci 15:213

4. Yadav MR, Kumar R, Parihar CM, Yadav RK, Jat SL, Ram H, Meena RK, Singh M, Birbal Verma AP, Kumar U, Ghosh A, Jat ML (2017) Indian J Anim Nutr 38:29

5. Schneider Teixeira A, Deladino L, Zaritzky N (2016) ACS Sustain Chem Eng 4:2449

6. Wezel A, Casagrande M, Celette F, Vian JF, Ferrer A, Peigné J (2014) Agron Sustain Dev 34:1

7. Perez JJ, Francois NJ (2016) Carbohydr Polym 148:134

8. Costa MM, Cabral-Albuquerque EC, Alves TL, Pinto JC, Fialho RL (2013) J Agric Food Chem 61:9984

9. Ni B, Liu M, Lü S, Xie L, Wang Y (2011) J Agric Food Chem 59:10169

10. Johnson JM, Wilhelm WW, Karlen DL, Archer DW, Wienhold B, Lightle DT, Laird D, Baker J, Ochsner TE, Novak JM (2010) Bioenerg Res 3:342

11. Rychter P, Kot M, Bajer K, Rogacz D, Siskova A, Kapusniak J (2016) Carbohyd Polym 137:127

12. Carter GA, Knapp AK (2001) Am J Bot 88:677

13. Chenard CH, Kopsell DA, Kopsell DE (2005) J Plant Nutr 28:285

14. Hardin IR (2007) Chemical treatment of textile dye effluent. Woodhead Publishing, Sawston p, p 191

15. Joo DJ, Shin WS, Choi JH, Choi SJ, Kim MC, Han MH, Ha TW, Kim YH (2007) Dye Pigment 73:59
16. Shiba R, Takahashi M, Ebisuno T, Takimoto M (1993) Bull Chem Soc Jpn 66:2452

17. Su ZX, Zhou YB, Chang XJ, Jin Y, Qi SK (2002) J Appl Polym Sci 84:962

18. Meng XL, Nie Y, Sun J, Cheng WG, Wang JQ, He HY, Zhang SJ (2014) Green Chem 16:2771

19. Kroneková Z, Pelach M, Mazancová P, Uhelská L, Trel'ová D, Rázga F, Némethová V, Szalai S, Chorvát S, McGarrigle JJ, Omami M, Isa D, Ghani S, Majková E, Oberholzer J, Raus V, Šiffalovič P, Lacík I (2018) Sci Rep 8:1637

20. Wang T, Lacik I, Brissova M, Anilkumar AV, Prokop A, Hunkeler D, Green R, Shahrokhi K, Powers AC (1997) Nat Biotechnol 15:358

21. Bucko M, Vikartovska A, Lacik I, Kollarikova G, Gemeiner P, Patoprsty V, Brygin M (2005) Enzyme Microbial Technol 36:118

22. Rokstad AM, Lacik I, de Vos P, Strand BL (2014) Adv Drug Deliv Rev 67-68:111

23. Gravastrand C, Hamad S, Fure H, Steinkjer B, Ryan L, Oberholzer J, Lambris JD, Lacík I, Mollnes TE, Espevik T, Brekke OL, Rokstad AM (2017) Acta Biomater 58:158. https://doi. org/10.1016/j.actbio.2017.05.052

24. Zhu ZL, Chen DL (2002) Nutr Cycl Agroecosyst 63:117

25. Liu YN, Li YC, Peng ZP, Wang YQ, Ma SY, Guo LP, Lin ED, Han X (2015) J Integr Agric 14:1184

26. Lan T, Han Y, Roelcke M, Nieder R, Cai Z (2013) Soil Biol Biochem 67:174

27. Di HJ, Cameron KC, Sherlock RR, Shen JP, He JZ, Winefield CS (2010) J Soils Sediments 10:943

28. Kelliher FM, Clough TJ, Clark H, Rys G, Sedcole JR (2008) Soil Biol Biochem 40:1878

29. Bhatia A, Sasmal S, Jain N, Pathak H, Kumar R, Singh A (2010) Agricult Ecosyst Environ 136:247

30. Schwarzer C, Haselwandter K (1991) Soil Biol Biochem 23:309

31. Amberger A (1986) J Plant Nutr Soil Sci 149:469

32. De Varennes A, Torres MO, Conceição E, Vasconcelos E (1999) J Plant Nutr 22:33

33. Hrdlicka L, Sramkova P, Prousek J, Kronek J (2018) Chem Pap 72:1543

34. PN-ISO 10390 (1997) Soil quality, Determination of pH Polish Committee for Standardization, Poland

35. PN-ISO $11265+$ AC1 (1997) Soil quality, Determination of the specific electrical conductivity Polish Committee for Standardization, Poland

36. Horwitz W (1980) AOAC official method of analysis. AOAC International, Rockville

37. PN-75/A-04018 Agricultural and food products, Determination of nitrogen by the Kjeldahl method and conversion into protein, Polish Committee for Standardization, Poland

38. OECD/OCDE (2006) Terrestrial plant test: seedling emergence and seedling growth test, In: OECD/OCDE Guidelines for the Testing of Chemicals, Section 2, Effects on Biotic Systems, Organization For Economic and Cooperation Development (OECD) Publishing

39. Lewkowski J, Morawska M, Karpowicz R, Rychter P, Rogacz D, Lewicka K (2017) Chemosphere 188:618

40. Oren A, Kuehl M, Karsten U (1995) Mar Ecol Prog Ser 128:151

41. Doe K, Scroggins R, Mcleay D, Wohlgeschaffen G (2005) Solid phase test for sediment toxicity using the luminescent bacterium, Vibrio fischeri. In small-scale freshwater toxicity investigations, In: Blaise C, Ferard JF, (eds) vol. 1. Springer, Dordrecht, The Netherlands, p 107-136

42. Microtox Acute Toxicity Test, MicrotoxÒ Manual, Azur Environmental (1998) Carlsbad, CA

43. Martínez-Sanchez MJ, Perez-Sirvent C, García-Lorenzo ML, Martínez-Lopez S, Bech J, García-Tenorio R, Bolívar JP (2014) J Geochem Explor 147:130 
44. Albornoz F (2016) Scienta Horticulturae 205:79

45. May WE, Mohr RM, Lafond GP, Johnston AM, Stevenson FC (2004) Can J Plant Sci 84:1025

46. Pervez MA, Ayub CM, Saleem BA, Virk NA, Mahmoode N (2004) Int J Agri Biol 6:504

47. Leghari SJ, Wahocho NH, Laghari GM, Laghari AH, Bhabhan GM, Talpur KH, Bhutto TA, Wahocho SA, Lashari AA (2016) Adv Environ Biol 10:209

48. Liu CW, Sung Y, Chen BC, Lai HY (2014) Int J Environ Res Public Health 11:4427

49. Jain V, Abrol P (2017) Management options, and policies, 11-plant nitrogen use efficiency. Elsevier, Amsterdam, p 163

50. Zhou QP, Biswas DK, Ma BI (2013) J Plant Nutr Soil Sci 176:929

51. Pandey RK, Maranville JW, Admou A (2000) Agric Water Manag 46:1

52. Akoumianakis KA, Karapanos IC, Giakoumaki M, Alexopoulos AA, Passam HC (2011) Int J Plant Prod 5:111

53. Booth BD, Murphy SD, Swanton CJ (2003) Weed ecology in natural and agricultural ecosystems. CABI, Wallingford, $\mathrm{p} 81$

54. Monaco TA, Mackown CT, Johnson TA, Norton JM, Norton JB, Redinbaugh MG (2003) J Range Manage 56:646

55. Baskin CC, Baskin JM (1998) Seeds: ecology, biogeography and evolution of dormancy and germination. Elsevier, Amsterdam

56. Fenner M (1991) Seed Sci Res 1:75

57. Bremner JM (1995) Fertil Res 42:321
58. Schimpf DJ, Palmblad IG (1980) Weed Sci 28:190

59. Nakano H, Makino A, Mae T (1997) Plant Physiol 115:191

60. Mozafar A (1993) J Plant Nutr 16:2479

61. Pagani A, Mallarino AP (2012) Soil Sci Soc Am J 76:1855

62. Cyanoguanidine, OECD SIDS, SIDS Initial Assessment Report For SIAM 17 (2003) UNEP Publications, Arona, Italy. http:// www.inchem.org/documents/sids/sids/461585.pdf

63. Che J, Zhao XQ, Zhou X, Ji ZJ, Shen RF (2015) Appl Soil Ecol $85: 21$

64. Jiang X, Hou X, Zhou X, Xin X, Wright A, Ji Z (2015) Soil Biol Biochem 81:9

65. Bremner JM (1990) Soil Use Manag 6:70

66. Darusman LR, Whitney DA, Janssen KA, Long JH (1991) Soil Sci Soc Am J 55:1097

67. Abbas M, Adil M, Ehtisham-ul-Haque S, Munir B, Yameen M, Ghaffar A, Shar GA, Tahir MA, Iqbal M (2018) Sci Total Environ 626:1295

68. Hernando MD, De Vettori S, Martinez Bueno MJ, Fernandez-Alba AR (2007) Chemosphere 68:724

Publisher's Note Springer Nature remains neutral with regard to jurisdictional claims in published maps and institutional affiliations. 